\title{
Efficiency Assessment of EAF-S Processing For Recycling Purpose by LCA Method
}

\author{
W. Chebbi, O. Yazoghli-Marzouk, M. Dauvergne, A. Jullien
}

\begin{abstract}
EAF slag is a by-product generated by steel production in an electric arc furnace (EAF). Generally, this by-product is not or less recycled in a next steel production and stored in the form of a dump (which takes increasingly space), because of the presence of significant amounts of impurities. Many studies have shown that slag may substitute for natural aggregate in the construction sector. But, because of the presence of heavy metals, EAF slag must be processed for the production of recyclable material regarding environmental recommendation for road construction. This paper presents the study of the environmental efficiency assessment of EAF slag processing for recycling using life cycle assessment (LCA). Two processes are compared. The efficiency assessment of the processes is based on the environmental "quality" of the produced material as well as on the environmental impact of the process. Thus technical characterization of the EAF slag was performed to verify its environmental "quality" based on its conformity to French standards and rules for use as road material. So, leaching tests were done, as the main property considered for recycling waste materials, in France, is their potential emission of pollutants to water. All collected experimental data are then used in order to compare the various impacts obtained for each process and discuss the interest of various solutions considering both toxicity and ecotoxicity indicators.
\end{abstract}

Keywords-EAF slag, recycling, road aggregate, process efficiency, LCA.

\section{INTRODUCTION}

About 12 million tons of steel slag are produced annually in Europe [1]. Considered as waste for a long time, this by-product is increasingly used in civil engineering applications as its valorization allows a number of benefits such as the conservation of natural resources, the reduction of waste storage volumes, the decrease of material construction cost and transport demands and the promotion of local economy [2-4]. Today, EAF slag is partially recycled as aggregates for earthworks [5, 6], for asphalt mixtures [7, 8], for mortar and concrete $[9,10]$ and for clinker manufacture [6]. But, recycling this by-product in such applications depends not only on its aptitude to reach technical specifications but also on its environmental compatibility including the leachability of harmuful elements like chromium, molybdenum and vanadium $[4,11,12,13]$.

EAF slag (EAF-S), from high alloy steel production, is

Manuscript received Sept. 15, 2015.

W. Chebbi, M. Dauvergne and Agnès Jullien are with LUNAM Université, Ifsttar, AME-EASE, Route de Bouaye, CS4, F-44341 Bouguenais, France

O. Yazoghli-Marzouk is with Cerema, Direction Territoriale Centre Est, DL Autun, Boulevard Bernard Giberstein, 71404 Autun, France. principally composed of silicon, calcium and iron but also contains traces of potential toxic elements as chromium, molybdenum and vanadium $[14,15]$. Previous studies on the environmental assessment of recycling this EAF-S [16] showed the interest of this recycling comparing to landfilling as well as EAF-S use in road layer comparing to natural sand use, based on LCA. As a result, EAF-S must be processed to produce a recyclable new resource for road construction. The choice of the optimal process depends not only on its monetary cost but also on its environmental cost. Thus, this paper presents the study of the environmental efficiency assessment of EAF-S processing for the production of recyclable material in road based on LCA. Two processes are compared. The efficiency assessment of the processes is based on the environmental "quality" of the produced material and on the environmental impact of the process. Thus characterization of the EAF slag was performed to verify its environmental "quality" based on its conformity to French standards and rules for use as road material. So, leaching tests were done, as the main property considered for recycling waste materials, in France, is their potential emission of pollutants to water. All collected experimental data are then used in order to compare the various impacts obtained for each process and discuss the interest of various solutions considering both toxicity and ecotoxicity indicators.

\section{Method AND MATERIAL PROPERTIES}

\section{A. Method}

Performing LCA as initiated by the SETAC [17] involves two main types of underlying objectives, leading to:

- Compare products (or processes). In that case, chosen systems only include materials, processes and life cycle steps, that may induce differences between compared products (or processes);

- Provide environmental information (for public and/or private organizations). Here, chosen systems may be much wider.

According to some authors, LCA is also a diagnosis tool that enables to improve the global environmental profile of any system considered. It may be decomposed into successive levels that depend upon the authors: 1/ system description, 2/ elementary process, 3/ flux calculations, 4/ build the appropriate model, 5/ analyze and interpret the results and do the report. The system usually gathers all the elementary processes that are defined as the "smallest unit of the system" with inputs and outputs related to the industrial operation of 
interest [18].

Two scenarios are considered in this study for the assessment of the process efficiency for the treatment and the production of a recyclable EAF-S in road construction by LCA calculation:

- $\quad$ process 1 use water for 24 hours (scenario 1)

- $\quad$ process 2 use acid for 2 hours (scenario 2)

Figure 1 indicates the scenarios of interest and LCIs (life cycle inventories) considered. The phases investigated are waste processing and stockpiling (temporary stocks).

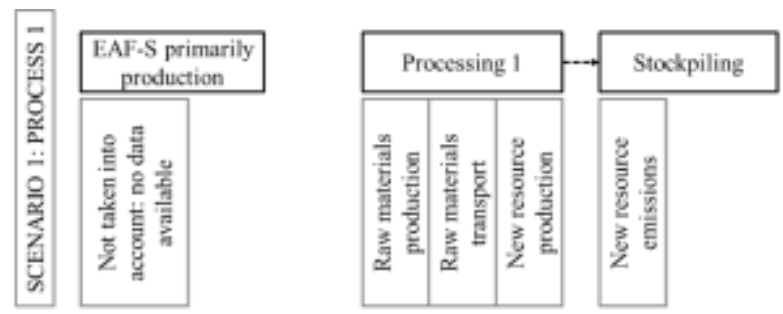

Scenario 1 : process 1 = processing $1+$ stockpiling

A $\begin{gathered}\text { EAF-S primarily } \\ \text { production }\end{gathered}$
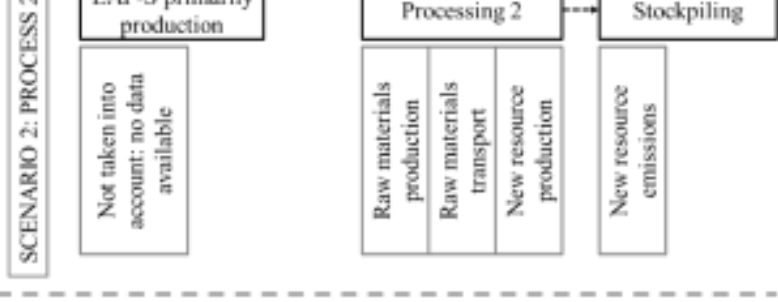

Scenario 2 : process 2 - processing $2+$ stockpiling

Fig. 1. The different scenarios investigated in this study and the LCIs analyses.

The calculation of impact indicators, according to a model explained in a previous work by [19], is described as:

$$
\text { Ind } j=\sum_{i} \alpha i j \times C i j \times m i
$$

with: Ind $\mathrm{j}$, indicator associated with impact category $\mathrm{j}$; mi, mass of inventory flow i $(\mathrm{kg})$; $\mathrm{Cij}$, contribution coefficient of inventory flow $\mathrm{i}$ to impact category $\mathrm{j}$; and $\alpha \mathrm{ij}$ : classification coefficient (from Goedkoop, 2001). Each indicator is expressed in specific units per kilograms or tons.

The contribution coefficients selected from the literature and implemented for the impact calculations, based on Equation (1), and the chosen impact categories (and indicators) derived from classical LCA comprise all references given in [19]:

Energy consumption: the specific energy consumption of each equipment (named CESP, as it is the French acronym for Specific Production-related Energy Consumption); Global Warming Potential (GWP), from IPCC (2001),

Toxic and Ecotoxic Potentials (TP and EP), from [20].

The efficiency assessment of the process is based on the environmental impact of the process itself (waste processing phase) and on the "environmental" quality of the new EAF-S produced (stockpiling phase). Therefore, leaching tests were performed on alternative material (EAF-S) produced by the two processes to characterize water release and toxic and eco toxic effects. The leaching tests are done on crushed aggregates according to NF EN 12457-4 (24 hours) [21]. The test consists of extractions of the material at liquid on solid ratio $(\mathrm{L} / \mathrm{S})$ equal to 10 by specific mixing. The leachant is demineralised water and the particle size is inferior to $4 \mathrm{~mm}$.

\section{B. Materials}

\section{1) Raw $E A F-S$}

The steel slag used is produced by an electric arc furnace (EAF-S). Its gap-grading analysis according to EN 933-1 European standard [22], shows that it can be assimilated to a $0 / 1 \mathrm{~mm}$ sand. Its humidity is $18 \%$ and its real bulk density is 2.5 $\left(\mathrm{t} / \mathrm{m}^{3}\right)$.

Chemical characterization of EAF-S shows (table I) that it is composed of $70 \%$ by weight of siliceous oxydes of silicium, calcium, aluminum and iron. It also contains metals (cupper $(\mathrm{Cu})$, nickel $(\mathrm{Ni})$, chromium $(\mathrm{Cr})$, molybdenum (Mo), vanadium $(\mathrm{V})$, zinc $(\mathrm{Zn}) . .$.$) .$

The results of leaching tests obtained for raw EAF-S (table II) are over the limits fixed by French guideline [13] and doesn't allow this EAF-S to be classified as inert waste and thus used as road material. So, it could be stored by landfilling or recycled if it is previously processed to produce new resource.

\begin{tabular}{ccc} 
TABLE I: CHEMICAL COMPOSITION OF RAW EAF-S (X-RAY FL \\
\hline \hline Elements & Units & EAF-S \\
\hline $\mathbf{S i O}_{2}$ & \% by weight & 32.9 \\
$\mathbf{T i O}_{2}$ & \% by weight & 0.4 \\
$\mathbf{A l}_{2} \mathbf{O}_{3}$ & \% by weight & 8.1 \\
$\mathbf{F e}_{2} \mathbf{O}_{3}$ & \% by weight & 14.1 \\
$\mathbf{M n O}$ & \% by weight & 1.5 \\
$\mathbf{M g O}$ & \% by weight & 3.9 \\
$\mathbf{C a O}$ & \% by weight & 15.8 \\
$\mathbf{N a} \mathbf{O}_{2} \mathbf{O}$ & $\%$ by weight & 0.2 \\
$\mathbf{K} \mathbf{O}_{2}$ & \% by weight & 0.8 \\
$\mathbf{P}_{2} \mathbf{O}_{5}$ & \% by weight & 0.2 \\
$\mathbf{A s}$ & $\mathrm{mg} / \mathrm{kg}$ & $<100$ \\
$\mathbf{C o}$ & $\mathrm{mg} / \mathrm{kg}$ & 275 \\
$\mathbf{C r}$ & $\mathrm{mg} / \mathrm{kg}$ & 18000 \\
$\mathbf{C u}$ & $\mathrm{mg} / \mathrm{kg}$ & 1040 \\
$\mathbf{M o}$ & $\mathrm{mg} / \mathrm{kg}$ & 589 \\
$\mathbf{N i}$ & $\mathrm{mg} / \mathrm{kg}$ & 1510 \\
$\mathbf{V}$ & $\mathrm{mg} / \mathrm{kg}$ & 426 \\
$\mathbf{Z n}$ & $\mathrm{mg} / \mathrm{kg}$ & 399 \\
$\mathbf{Z r}$ & $\mathrm{mg} / \mathrm{kg}$ & 1350 \\
\hline \hline & & \\
\hline
\end{tabular}

\section{2) Processed EAF-S for recycling purpose}

Aggregates are produced with respect to their potential use. Thus they are processed to reach the required grading and thereby ensure marketability. As regards the environment and depending on the types of operations performed, recycling generates various impacts as a result of raw material transformation or processing and stockpiling as described in figure I. In this study the impacts of the phases corresponding to 
transport and use in road are not considered, as we assess the efficiency of the process used to produce recyclable material (processed EAF-S).

Such impacts are directly correlated with electricity consumption, emission releases into the air and water, as well as waste production. In this study, at stockpiling phase, the output flux considered for EP and TP calculation is release into water. Thus, analyses of raw EAF-S and processed EAF-S by process 1 and 2 (table II) were conducted to determine the presence of various compounds and elements with dangerous characteristics. This used leaching by lixiviation tests, according to NF EN 12457-4 (24 hours) [21].

\begin{tabular}{|c|c|c|c|}
\hline Elements & $\begin{array}{l}\text { Raw } \\
\text { EAF-S } \\
(\mathrm{mg} / \mathrm{kg})\end{array}$ & $\begin{array}{l}\text { EAF-S after } \\
\text { process } 1 \\
(\mathrm{mg} / \mathrm{kg})\end{array}$ & $\begin{array}{l}\text { EAF-S after } \\
\text { process } 2 \\
(\mathrm{mg} / \mathrm{kg})\end{array}$ \\
\hline $\mathrm{Al}$ & 73.9 & 81.1 & ND \\
\hline As & $210^{-3}$ & $210^{-3}$ & $<0.20$ \\
\hline $\mathrm{Ba}$ & 1.258 & 0.47 & 0.30 \\
\hline $\mathrm{Ca}$ & 793.4 & 766.6 & ND \\
\hline $\mathrm{Cd}$ & $<\mathrm{LQ}$ & $10-3$ & 0.003 \\
\hline $\mathrm{Cr}$ & 1.73 & 0.53 & 0.43 \\
\hline $\mathrm{Cu}$ & 0.23 & $610^{-2}$ & $<0.20$ \\
\hline $\mathrm{Fe}$ & 3.99 & 5.26 & ND \\
\hline $\mathrm{Hg}$ & $<\mathrm{LQ}$ & $<\mathrm{LQ}$ & $<0.001$ \\
\hline K & 135.0 & 51.96 & ND \\
\hline $\mathrm{Mg}$ & 1.701 & 2.22 & ND \\
\hline $\mathrm{Mn}$ & 0.413 & 0.55 & ND \\
\hline Mo & 15.44 & 4.89 & 3.91 \\
\hline $\mathrm{Na}$ & 116.1 & 29.07 & ND \\
\hline $\mathrm{Ni}$ & 0.105 & $1.310^{-2}$ & $<0.1$ \\
\hline $\mathrm{Pb}$ & $<\mathrm{LQ}$ & $<\mathrm{LQ}$ & $<0.1$ \\
\hline $\mathrm{Sb}$ & $<\mathrm{LQ}$ & $<\mathrm{LQ}$ & 0.02 \\
\hline $\mathrm{Se}$ & 0.1 & $710^{-2}$ & 0.027 \\
\hline $\mathrm{Si}$ & 68.99 & 59.67 & ND \\
\hline $\mathrm{Zn}$ & $610^{-2}$ & $510^{-3}$ & 0.4 \\
\hline $\mathrm{F}^{-}$ & 81.5 & 32.3 & 60.4 \\
\hline $\mathrm{Cl}^{-}$ & 62.5 & 10.8 & 49.0 \\
\hline $\mathrm{SO}_{4}{ }^{2-}$ & 518.5 & 206 & 121 \\
\hline
\end{tabular}

The results of leaching test on the new resources (processed EAF-S by process 1 and 2) show that the values are below the limits fixed by French guideline [13]. So, processed EAF-S are considered as an inert material and can be used as road material (French order of March 15th fixing the list of admissible inert wastes in inert waste storage or deposits and the conditions of their exploitation, annex II).

\section{PROCESS EFFICIENCY ASSESSMENT BY LCA}

The efficiency assessment of the processes is based on the environmental impact of the process and on the environmental "quality" of the produced material. The environmental impact of the process takes into account (as described in fig. I) the LCI for the production of new resource (recyclable EAF-S) which consist of the creation of process/treatment installation and process/treatment functioning. It also considers the production of raw materials (like acid for process 2) and the transport of raw material to the plant for processing. The environmental "quality" of the new resource is its potential emission of chemical substances during its stockpiling phase. Its traduce the efficiency of the process to produce recyclable materials (as regards environmental and road recommendations).

Process 1 (water treatment; 24 hours) and process 2 (acid; 2 hours) are compared. The time scale (long or short term) considered for the loadings is short term (100 years).

TABLE III: COMPARISONS OF IMPACTS FOR SCENARIO 1 (PROCESS 1) AND SCENARIO 2 (PROCESS 2) FOR THE PROCESSING OF 400,000 TONS OF EAF-S

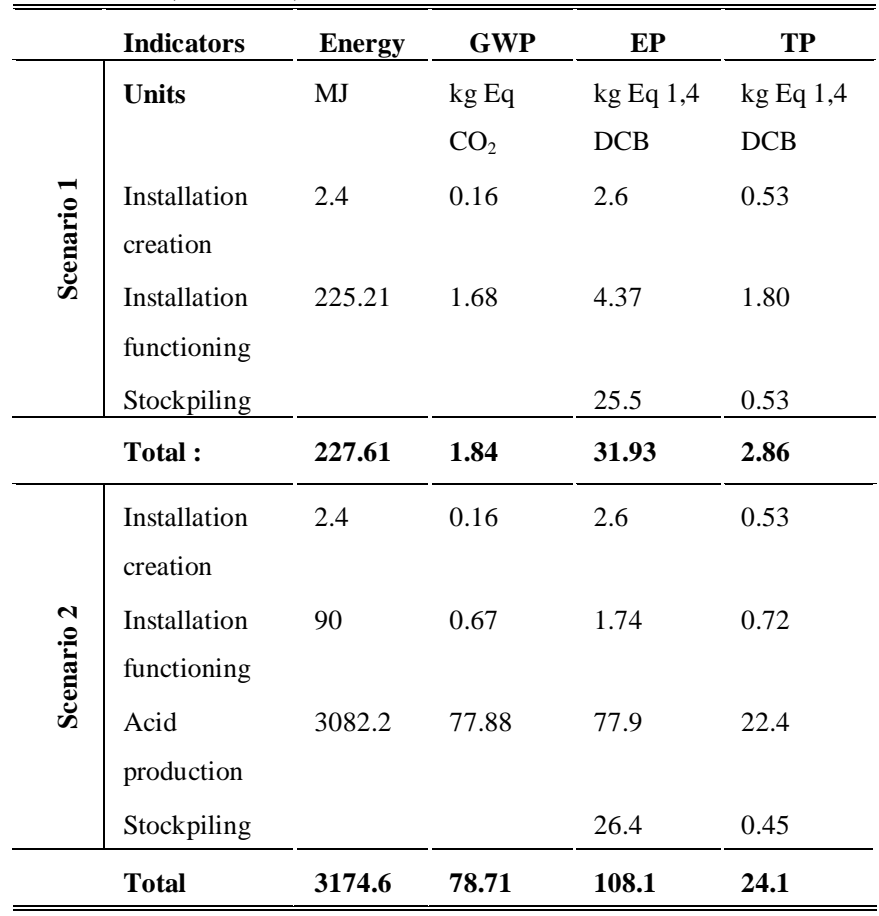

GWP: global warming potential, EP: ecotoxic potential, TP: toxic potential.

Table 4 shows the interest of scenario 1 compared to scenario 2. The impacts predictions for all the indicators of scenario 1 are clearly higher than those of scenario 2 . The difference comes from the impacts predictions for acid. When we look to the impact of products (processed EAF-S) during stockpiling (the environmental "quality" of the products traduced by their EP and TP), we see that the two processes produce two products with almost the same environmental "quality".

\section{CONCLUSION}

This paper presents a case study of the efficiency assessment of two EAF-S (electric arc furnace slag) processes, for the production of recyclable material in road construction, using life cycle assessment (LCA). We propose that the efficiency assessment of the processes is not only based on the environmental impact of the process but also on the environmental "quality" of the produced material. Two processes were analyzed (scenario 1: acid treatment and scenario 2: water treatment). For each process, the environmental impacts of the process creation and its functioning as well as the environmental impact of the produced material (new resource for road application) were 
evaluated by Energy, Global Warming Potential, Ecotoxic Potential and Toxic Potential indicators. Considering that the release of chemicals from EAF-S occurs after its processing, leaching tests were performed on the produced EAF-S and the indicators EP and TP were calculated.

The results obtained show that the impacts predictions for all the indicators are higher in scenario 2 compared to scenario 1 . The difference is clearly significant for energy and global warming potential. This difference originates from the impacts predictions for acid. Furthermore, the impacts predictions for EP and TP of products (processed EAF-S) during stockpiling show that these products have almost the same environmental "quality".

Thus, this study shows the efficiency of the process 1 compared to process 2 based on LCA. The international literature does not give such kind of results in our knowledge.

\section{REFERENCES}

[1] H. Motz and J. Geiseler, "Products of steel slags an opportunity to save natural resources" Waste Management, vol. 21, pp. 285-293, 2001. http://dx.doi.org/10.1016/S0956-053X(00)00102-1

[2] T. Eighmy and W. Chesner, "User guidelines for byproducts and secondary use materials in pavement construction". Federal highway administration R\&D center, 2000. (FHWA-RD-148). The document is available on http://www.rmrc.unh.edu

[3] M.J. Simon, W. Chesner, T. Eighmy, H. Jongedyk, "National research projects on recycling in highway construction" vol. 64. $n^{\circ} 1,2006$.United States department of transportation. Federal highway administration.

[4] Ofrir (2010). Observatoire Français du Recyclage dans les Infrastructures Routières. http://ofrir2.ifsttar.fr

[5] K. Matern, T. Rennert, T. Mansfeldt, "Molybdate adsorption from steel slag eluates by subsoils" Chemosphere, vol. 93, pp. 2108-2115, 2013. http://dx.doi.org/10.1016/j.chemosphere.2013.07.055

[6] D. Xirouchakis and V. Monalakou, "Properties of an EAF slag production in Greece: a construction material for sustainable growth". $5^{\text {th }}$ International Conference Bituminous mixtures and pavements, 2-3 June 2011, Thessaloniki, Greece.

[7] V. Ducman, A. Mladenovic, "The potential use of steel slag in refractory concrete" Materials characterization, vol. 62, pp 716-723, 2011 http://dx.doi.org/10.1016/j.matchar.2011.04.016

[8] S. Sorlini, A. Sanzeni, L. Rondi, «Reuse of steel slag in bituminous paving mixtures", Journal of Hazardous Materials, vol. 209-210, pp. 84-91, 2012. http://dx.doi.org/10.1016/j.jhazmat.2011.12.066

[9] J.M. Manso, J.A. Polanco, M. Losanez, J.J. Gonzalez, "Durability of concrete made of EAF slag as aggregate", Cement and concrete composites, vol. 28, pp. 528-534, 2006 http://dx.doi.org/10.1016/j.cemconcomp.2006.02.008

[10] S. Abu-Eishah, A. El-Dieb, M. Bedir, "Performance of concrete mixtures made with electric arc furnace (EAF) steel slag aggregate produced in Arabian Gulf region", Construction and Building Materials, vol. 34, pp. 249-256, 2012. http://dx.doi.org/10.1016/j.conbuildmat.2012.02.012

[11] M. Reuter, Y. Xiao, U. Boin, "Recycling and environmental issues of metallurgical slags and salt fluxes". VII International Conference on Molten Slags Fluxes and Salts, the South African Institute of Mining and Metallurgy, Johannesburg, 2004.

[12] L. Château, "Environmental acceptability of beneficial use of waste as construction material: State of knowledge, current practices and future developments in Europe and in France". Journal of Hazardous Materials, vol. B139, 556-562, 2007. http://dx.doi.org/10.1016/j.jhazmat.2006.02.064

[13] SETRA, "French Environmental legislation. Acceptabilité de matériaux alternatifs en technique routière, évaluation environnementale". [Acceptability of alternative materials in road: environmental evaluation], Ed. Sétra 2011, 28pp.

[14] S. Schüler, H.P. Markus, D. Algermissen, D. Mudersbch, "Electric arc furnace slag engineering during production, treatment, solidification and processing". Proceeding of the 4th International slag valorisation symposium Zero waste, 15-17 April 2015, Leuven, Belgium.

[15] Fällman, A-M. (2000). "Leaching of chromium and barium from steel slag in laboratory and field tests - a solubility controlled process?" Waste Management vol. 20, pp. 149-154, 2000. http://dx.doi.org/10.1016/S0956-053X(99)00313-X

[16] Chebbi, W., Yazoghli-Marzouk, O., Dauvergne, M., Lumière, L. and Jullien, A., "Environmental assessment of EAF slag in different "end of 2nd life", Proceeding of RW-2nd International Conference on Civil and Environmental Engineering- December 26, 2015 - New York, USA

[17] SETAC (1993). Guidelines for Life-Cycle Assessment: a "code of practice". Ed. SET AC Foundation for Environmental Education, Florida 1993

[18] AFNOR ISO 14040 (2006). Management environnemental - Analyse du cycle de vie - Principes et cadres, Environmental management - Life cycle assessment - Requirements and guidelines, in: I.O.f. Standardization (Ed.), ISO 14040:33-46

[19] Sayagh S., Ventura A., Hoang T., François D., Jullien A., "Sensitivity of the LCA allocation procedure for BFS recycled into pavement structures", Resources Conservation and Recycling, vol. 54, pp. 348-358, 2010 http://dx.doi.org/10.1016/j.resconrec.2009.08.011

[20] M.A.J. Huijbregts, U. Thissen, T. Jager, D. van de Meent, A.M.J. Ragas "Priority assessment of toxic substances in life cycle assessment. Part II: assessing parameter uncertainty and human variability in the calculation of toxicity potentials", Chemosphere, vol. 41, Issue 4, pp. 575-588, August 2000.

http://dx.doi.org/10.1016/S0045-6535(00)00031-X

[21] AFNOR (2002). French standard NF EN 12457-4: "Characterization of waste - Leaching - Compliance test for leaching of granular waste materials and sludges - Part 2: one stage batch test at a liquid to solid ratio of $10 \mathrm{l} / \mathrm{kg}$ for materials with particle size below $4 \mathrm{~mm}$ (without or with size reduction)". AFNOR, December, 2002.

[22] AFNOR. (2012). French standard NF EN 933-1 : "Essais pour déterminer les caractéristiques géométriques des granulats - Partie 1 : détermination de la granularité - Analyse granulométrique par tamisage", AFNOR, May 2012 